\title{
Growing old has been my life's work
}

Previously published at www.cmaj.ca

$\mathrm{V}$ ows of marriage. Oaths of citizenship. A jury's verdict. Words with the power to change our identities are usually spoken in public places. But a cancer diagnosis is almost always delivered within a private conversation that takes place, unwitnessed, behind the closed door of a doctor's office, on the phone, or, most unceremoniously of all, in a hospital room - where, on the other side of the curtain, a television blares, a roommate is served lunch and a cleaning staff member mops the floor.

At age 20, while lying on a hospital bed in my own hometown, I was diagnosed with bladder cancer. Before my physician shared the bad news, he asked my visitors - who were missing the first day of college classes to be with me - to step out.

Then he pulled the curtain.

A few minutes later, he told my friends in the hallway, not unkindly, that they could come back in. And they did — although they left soon after, tiptoeing out of the room, as though the hushed behaviour we used in the library was what was required now that I had cancer.

From my fourth-floor window, I watched as they crossed the parking lot and drove away. A construction crew arrived. Women carried flowers into a church. Mallard drakes splashed in the park lagoon. A high school team ran wind sprints across an athletic field. My high school. My church. The lagoon where, as a child, I had caught a fish. How strange. The familiar world, full of jackhammers, ducks, and Bible study, was rolling its regular programming, as if nothing extraordinary had just happened. As if I had not just been culled from my own life. Or so it felt to me then.

Perhaps because the rituals of being a cancer patient are so far removed from public life, we sometimes presume its causes are likewise located in an interior, intimate place. We blame

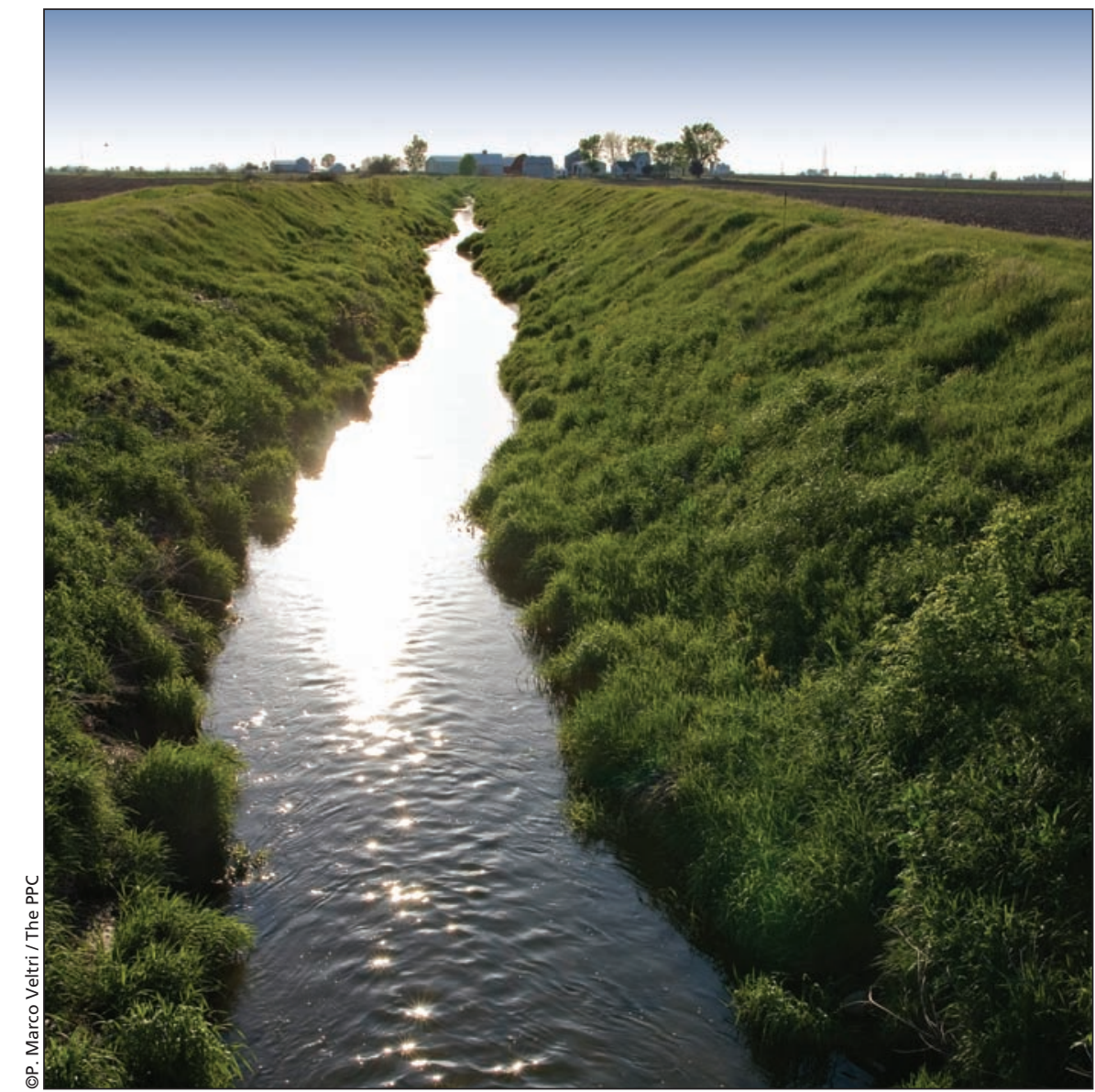

our private behaviours or our genes themselves, which we've inherited, like so many place settings of china, from our personal ancestors.

And some of the roots of cancer are indeed found there. But cancer has a public dimension, too. Our genes reside within cells, and cells reside within living bodies that, in turn, reside within particular public environments. And, as we breathe, bathe, eat, and walk the dog, our environment - with its carbon cycles and rivers, pollination systems and aquifers, industries and farms, geologies and jet streams - comes to reside inside us.

Thirty years ago, during our private conversation behind a gray, hospital curtain, while my friends waited in the hallway, my diagnosing physician assured me that, whatever the future held, he would take care of me. And he did. Sandra, let's grow old together, he would often laugh. Growing old has been my life's work as a cancer survivor.

But within that same conversation, my doctor also asked me some pointed questions about my possible past exposures to toxic chemicals. His questions that day let me know that bladder cancer is, by and large, an environmental disease. Understanding the public story of cancer became my life's work as a biologist.

\section{Sandra Steingraber PhD}

Ecologist and environmental advocate Ithaca, USA

Dr. Steingraber's diagnosis was the starting point for her book Living Downstream (A Merloyd Lawrence book; 2010) and a new feature-length documentary of the same title (see review at www.cmaj.ca). 